\title{
Brief Introduction on Innovative Education and Basic Physical Education Reform
}

\author{
Jianying Hao \\ NanChang Institute of Technology, Nanchang,330044।
}

\begin{abstract}
Keywords: Innovative educational philosophy; Basic physical education; Physical education teaching method
\end{abstract}

\begin{abstract}
The reform of PE teaching method focuses more and more on the combination of educational theory and practice, developing from a single trend to integration. Innovative education is the extension, expanding and deepening of quality education, and it is an important way to cultivate high quality creative talents. Through the study of PE teaching method under the concept of innovative education, it can not only promote PE teachers to renew their concept, change their roles, improve the quality and efficiency of teaching, but also create a learning environment with independent thinking, the courage to explore and continuous innovation, help students master learning methods to form correct practice attitude and sports values. Through the experiment, this paper compares the different effects of the physical education teaching methods of "learning-oriented" and "teaching-oriented" in enhancing students' constitution, improving learning efficiency and cultivating innovation consciousness.
\end{abstract}

\section{Introduction}

Basic education is the cornerstone of national education and the critical stage to cultivate people, as well as the basis to implement the task of "science and education strategy, comprehensively promoting the reform and development of education, to improve the quality of the nation and innovation ability". It shoulders the task of social development, personnel cultivation, and must be strengthened and improved.

The implementation of basic education is completed mainly through the teaching activities. The process of teaching activities "is a unified process of contact and practice activities, forming harmonious developed personality after cognition activities and activities of reforming subjective world for the existing human's knowledge and experience. It is also a series of methods for teachers and students to complete the teaching task, to enable students to master the knowledge and skills, and develop their ability.

The completion of teaching activities is inseparable from the support of teaching methods. The teaching method is the method that teachers and students complete the teaching task and realize teaching goal. It is an important category of teaching and learning theory and the methodology basis of teaching activities. Its effectiveness relates to the realization of teaching objectives and the degree of realization. With the infiltration of new ideas, new concepts in physical education, many new methods of physical education emerge.

\section{The Connotation and Importance of Physical Education Teaching Method under the Idea of Innovative Education}

With the advent of the era of knowledge economy, innovative education has become an important way and means to promote quality education. The so-called innovative education is to promote students' comprehensive and sustainable development and stimulate students' creative consciousness through education, to cultivate students' innovation ability. The innovation of physical education teaching method mainly refers that through the innovation and improvement of the existing methods and theories of physical education in the teaching of physical education, so as to realize the social value of physical education teaching. 
Traditional physical education teaching only focus on students with better sports talent, making them become outstanding sports reserve talents through active training. And the physical education under innovative education concept is to learn the essence of traditional education, combining the characteristics of the times and needs of modern students. The overall development of students is taken as the starting point, and all students are the core, so that the potential of most students can be developed. Through the combination of theory and practice, class and extracurricular activities, physical education and intellectual education, stimulate and cultivate students' creative ability, so as to achieve the purpose of cultivating creative talents with comprehensive quality. Physical education is very different with other disciplines that students not only need to invest a lot of physical strength to practice, but also invest intelligence for positive thinking. Therefore, in the practice of physical education under the concept of innovative teaching practice, as the organizers of teaching, physical education teachers must change the concept of education and closely focus on this main line of cultivating innovative talents, to cultivate and tap the students' sports potential, respecting the students' subjectivity, improving the quality of students in all directions, enhancing students' ability to innovate, to achieve the comprehensive development of students.

\section{The Present Situation of basic Physical Education}

In recent decades, traditional physical education has been used in the past to play a positive role in training personnel, but with the progress of society, traditional education has been unable to adapt to the needs of current educational development. In the cultivation of innovative talent, there are obvious limitations, and its main performance is as follows:

Teachers are oriented. The traditional physical teaching method curbing students to play their subjectivity takes teachers as the center. Before the physical education lesson, focusing on the self-designed teaching methods, taking how to "teach" as a starting point for research, the lesson only implements "teaching" process, with the purpose of completing subjective design, ignoring the students' subjective initiative and personality differences as an independent personality. Most of the lessons use indoctrination, imparting way of teaching, so that the learning development process becomes the process of teacher starring, and the students become the passive recipients of teaching process, thus inhibiting the students 'potential and full development of personality, so it is not conducive to cultivating the students'

The status of physical education is generally not high

As the whole society has long been affected by the examination-oriented education, physical education courses are generally not taken seriously. Most of the schools still put the cultural knowledge learning in the first place. It's common that physical education courses give concessions for other courses. Teachers cannot correctly understand the importance of physical education, thus physical education has low status, teachers. Teachers' teaching enthusiasm is low, leading to PE lesson cannot be implemented or play a good role.

Students generally with low physical fitness

According to the survey of China Youth Research Center, the physical health of the students in primary and secondary schools in China is not optimistic. Despite the continuous improvement in people's living standards, the trend of physical decline has not been significantly improved, and the health level is not optimistic. Over the past 20 years, although height and weight of students are increased a lot, but in speed, endurance, flexibility, explosive power, strength and other qualities, as well as the lung function that reflecting lung capacity and other physical indicators continue to decline.

\section{Educational Innovation Mode}

Cultivation-orientation, the implementation of innovative education

Physical education insists cultivation-orientation and innovative education, that is, taking the students as the main body, teachers as the leading, giving full play to the initiative of the students; constantly reforming the teaching content, methods and means to improve the quality of physical 
education, and promote the physical and mental health of students; strengthening teaching and learning ability, innovation ability of students, making them learn knowledge and skills, learn to work, learn to live, learn to behave; initiating the education method of innovative physical education, such as heuristic teaching, exploratory teaching, discussion teaching, etc., to help students to learn and improve their ability to learn, stimulate students' curiosity for learning, cultivate students interest in learning, and create good environment with independent thinking, free exploration and the courage to innovate.

Improve learning efficiency, to meet the needs of curriculum reform

Over more than 10 years of the new curriculum experiment and implementation of physical education, the concept continuously impact physical education, physical education teaching methods are constantly changing and innovated. The starting point of curriculum reform is students. Students' learning effect, ability cultivation are the measure of curriculum reform. What the students want to get from the physical education is often a far from the actual teaching, leading students becoming very disappointed, losing the confidence and enthusiasm of the exercise. The study of physical education teaching methods not only to reveal the problems of physical education curriculum reform and solve the confusion of first-line physical education teachers, but also to promote students like physical education, actively participate in sports activities to provide help and reference.

Enhance students' physical fitness, explore teaching methods

The physical and mental decline in primary and secondary school students become an indisputable fact that school physical education should be responsible. Although the decline in physical fitness is not unilaterally caused by school physical education, but the main way to improve the physical health of young people is school physical education, which is the responsibility of PE workers and obligations. As we all know, a reasonable teaching method not only can make the teaching effect more with less, and make students benefit for life. Whether the methods of teaching organization or the methods to guide students to practice, they will all affect the enthusiasm and initiative of students to learn, but also affect the students' habit cultivation of exercise in the future, it can be said that the study of physical education is the effective way to promote young people students' physical health.

\section{Conclusion}

The idea of innovative education is an educational idea, highlighting the ability to cultivate students. Its core is composed of innovation consciousness and innovation ability, and has a guiding effect on the reform of PE teaching methods. Physical education teaching methods is the teaching activities measures that teacher and student achieve the goal of physical education, and completes teaching tasks by using a series of teaching strategies, organizational methods, specific means; it's divided into two categories of "teaching-oriented" physical teaching method and "learning-oriented" physical education teaching method. The design of physical education teaching method should follow the principles of fitness, diversity, selectivity, fun and so on. Teaching method innovation should start from the teaching elements as a whole, for reasonable arrangement; consider, expand and improve from the actual situation; considering from the teaching effect, optimize and combine; starting from the future development of students, perform integrated selection.

\section{References}

[1] Garn A C, Wallhead T. Social goals and basic psychological needs in high school physical education.[J]. 2015, 4(2):88-99.

[2] Salimin N, Shahril M I, Jani J, et al. Development Assessment Instrument for Basic Skills of Invasion in Physical Education[J]. Advanced Science Letters, 2017.

[3] Garn A C, Wallhead T. Social goals and basic psychological needs in high school physical education.[J]. 2015, 4(2):88-99.

[4] Vlachopoulos, Symeon P.|Katartzi, Ermioni S.|Kontou, Maria G The Basic Psychological Needs in Physical Education Scale.[J]. Journal of Teaching in Physical Education, 2011, 30(3):263-280. 
[5] Santurio J I M, Fernandez-Rio J. Spanish Version of the Basic Psychological Needs in Physical Education Scale[J]. 2016.

[6] Chen N. Analysis on the National Basic Skill Contest For Students Majoring in Physical Education[J]. Journal of Chehgdu Physical Education Institute, 2000.

[7]Mao Y P, Qi-Zhou G U. Explore the Basic Idea of College Physical Education Team Building[J]. Journal of Nanjing Sport Institute, 2014.

[8] Méndez-Alonso D, Méndez-Giménez A, Fernández-Río J. Integrating the basic competences into physical education in primary education[J]. 2015, 61(61).

[9] Salimin N, Shahril M I, Jani J, et al. Development Assessment Instrument for Basic Skills of Invasion in Physical Education[J]. Advanced Science Letters, 2017.

[10]Gui X, University C N. On Curriculum of Rural Basic Education Physical Education Teachers' Training[J]. Guide of Science 、 Education, 2014.

[11]Bin L I. Change, Conflict and Integration of Physical Education and Health Course Reform in Basic Education: An Axiology Perspective[J]. Journal of Beijing Sport University, 2016.

[12]Méndez-Alonso D, Méndez-Giménez A, Fernández-Río J. Integrating the basic competences into physical education in primary education[J]. 2015, 61(61). 